\title{
The global burden of neonatal hypothermia: systematic review of a major challenge for newborn survival
}

\author{
Karsten Lunze ${ }^{1 *}$, David E Bloom², Dean T Jamison ${ }^{3}$ and Davidson H Hamer ${ }^{4,5}$
}

\begin{abstract}
Background: To provide evidence on the global epidemiological situation of neonatal hypothermia and to provide recommendations for future policy and research directions.

Methods: Using PubMed as our principal electronic reference library, we searched studies for prevalence and risk factor data on neonatal hypothermia in resource-limited environments globally. Studies specifying study location, setting (hospital or community based), sample size, case definition of body temperature for hypothermia, temperature measurement method, and point estimates for hypothermia prevalence were eligible for inclusion.

Results: Hypothermia is common in infants born at hospitals (prevalence range, 32\% to 85\%) and homes (prevalence range, $11 \%$ to $92 \%$ ), even in tropical environments. The lack of thermal protection is still an underappreciated major challenge for newborn survival in developing countries. Although hypothermia is rarely a direct cause of death, it contributes to a substantial proportion of neonatal mortality globally, mostly as a comorbidity of severe neonatal infections, preterm birth, and asphyxia. Thresholds for the definition of hypothermia vary, and data on its prevalence in neonates is scarce, particularly on a community level in Africa.

Conclusions: A standardized approach to the collection and analysis of hypothermia data in existing newborn programs and studies is needed to inform policy and program planners on optimal thermal protection interventions. Thermoprotective behavior changes such as skin-to-skin care or the use of appropriate devices have not yet been scaled up globally. The introduction of simple hypothermia prevention messages and interventions into evidence-based, cost-effective packages for maternal and newborn care has promising potential to decrease the heavy global burden of newborn deaths attributable to severe infections, prematurity, and asphyxia. Because preventing and treating newborn hypothermia in health institutions and communities is relatively easy, addressing this widespread challenge might play a substantial role in reaching Millennium Development Goal 4, a reduction of child mortality.
\end{abstract}

Keywords: hypothermia, mortality, neonatal, newborn, prematurity

\section{Background}

The global burden of neonatal deaths and its relation to hypothermia

The global under -5 child mortality rate has decreased continuously during the last three decades, from 110 per 1,000 in 1980 to 60 per 1,000 in 2009 , and the number of child deaths worldwide each year has decreased

\footnotetext{
* Correspondence: karsten.lunze@post.harvard.edu

'Boston University School of Medicine, 801 Massachusetts Avenue,

Crosstown 2077, Boston, Massachusetts 02118, USA

Full list of author information is available at the end of the article
}

from 13.5 million in 1980 to an estimated 7.7 to 8.8 million in 2008 [1-4]. The number of neonatal deaths (newborns dying under the age of 28 days) has also decreased, from 4.6 million deaths in 1990 to approximately 3.1 to 3.6 million in 2009 [3,5]. However, neonatal mortality has declined at a lower rate than child mortality, so the proportion of newborn deaths among all child deaths has been increasing.

Neonatal deaths are unequally distributed around the globe. Half of the world's newborns die at home, and more than $99 \%$ of all deaths occur in developing
Ciomed Central 
countries, where the average neonatal mortality rate is 33 per 1,000, compared with 4 per 1,000 in high-income countries. Since neonatal deaths account for more than $40 \%$ of under -5 mortalities [3], reaching Millennium Development Goal (MDG) 4 will require a substantial reduction in newborn mortality. Although addressing neonatal hypothermia might facilitate this goal, it has so far been a neglected challenge. Maintaining a normal body temperature is a critical function for newborn survival. Newborns achieve this through sophisticated mechanisms of body temperature regulation controlled by the hypothalamus and mediated by endocrine pathways through shivering and non-shivering thermogenesis [6]. However, particularly in premature and low birth weight infants, thermoregulatory mechanisms are easily overwhelmed, leading to metabolic deterioration and direct death from hypothermia or indirect mortality from associated mortalities such as severe infections [7].

The attribution of neonatal hypothermia to indirect or direct causes of newborn death is complex and difficult for several reasons. Most neonatal deaths occur in regions without vital registrations or other reliable data sources. In countries where neonatal deaths are estimated to be highest, mortality data are based on national sample death registration at best [3] and mostly rely on verbal autopsy data-based models with less-than-optimal sensitivity and specificity to correctly identify causes of deaths [8]. Only $2.5 \%$ of global neonatal deaths data are based on reliable vital registration systems [9], while 97\% derive from systematic estimations or household surveys [10].

Moreover, causes of death are difficult to ascertain in newborns because, especially at the beginning of life, infants exhibit few specific symptomatic reactions to illnesses. Clinical manifestations of various diseases overlap considerably in neonates. Early deaths and those in very small babies are often misclassified due to varying definitions of stillbirth and neonatal deaths, or due to other misreporting of data, such as avoiding filling out death certificates [8].

Globally, severe infections account for an estimated 36\% of all neonatal deaths, while problems associated with prematurity account for another $29 \%$, and birth asphyxia makes up 23\% (with congenital malformations and a variety of other causes responsible for $19 \%$ of neonatal deaths) [3]. While all these causes of death are associated with neonatal hypothermia, the direction of causality is unclear [7]. Although usually infections (mostly sepsis and pneumonia) are listed as cause of death rather than hypothermia, it is unclear whether hypothermia is the underlying cause or the consequence of severe infections. Like severe infections, prematurity is associated with mortality from hypothermia. While only half of the babies born are weighed at birth (and even fewer are of known gestational age), it is estimated that annually 18 million, or $14 \%$ of all babies, are born with low birth weight (LBW), half of them in South Asia. LBW infants account for $60 \%$ to $80 \%$ of neonatal deaths. Birth asphyxia is associated with hypothermia, and prevention or treatment of hypothermia is an important therapeutic principle during and after resuscitation in both developing and developed settings $[11,12]$.

Daily mortality rates for the neonatal period are 30 -fold higher than later during infancy [10]. Immediately after birth, an infant is at highest risk of dying, with $25 \%$ to $45 \%$ of neonatal mortality occurring during the first $24 \mathrm{~h}$ [10] and $75 \%$ of neonatal mortality during the first week of life [13]. Assuming that early deaths are caused mainly by prematurity and asphyxia, interventions addressing hypothermia management and resuscitation might have a substantial impact on neonatal mortality prevention.

This review analyzes the global epidemiological situation of neonatal hypothermia for the purpose of guiding future policy and research efforts.

\section{Methods}

We identified studies providing data on the epidemiology of and potential risk factors for neonatal hypothermia, with the search focused on low-income and middle-income countries. This review followed the Preferred Reporting Items for Systematic Reviews and Meta-Analyses (PRISMA) guidelines where applicable [14]. Rather than reviewing only intervention studies on hypothermia and assessing their quality, we reviewed any references with data on the magnitude of hypothermia prevalence as observational outcome or at study baseline. For this analysis, we included individually specified hypothermia threshold definitions for each study in our results summary. We conducted a broad PubMed search of peer-reviewed published papers without date or language restrictions, limited to low-income or middleincome countries. The search (see flowchart in Figure 1) included $\mathrm{MeSH}$ terms and keywords, combinations, and snowball searching in references of pertinent papers for related articles. The initial search terms used were (('Hypothermia'[MeSH]) OR 'Body Temperature Regulation'[Majr:NoExp]) AND ('Infant, Newborn'[MeSH] OR 'neonatal'), and included various combinations of these and the terms 'thermoregulation', 'body temperature regulation', and 'heat loss'. The lead author scanned 918 titles and retrieved 360 relevant abstracts. All citations providing newborn hypothermia prevalence estimates or data from which this could be calculated for a lowincome or middle-income country (as defined by the World Bank [15]) were deemed eligible for inclusion in this review. Only studies fulfilling criteria determined prior to the literature research were applicable for 


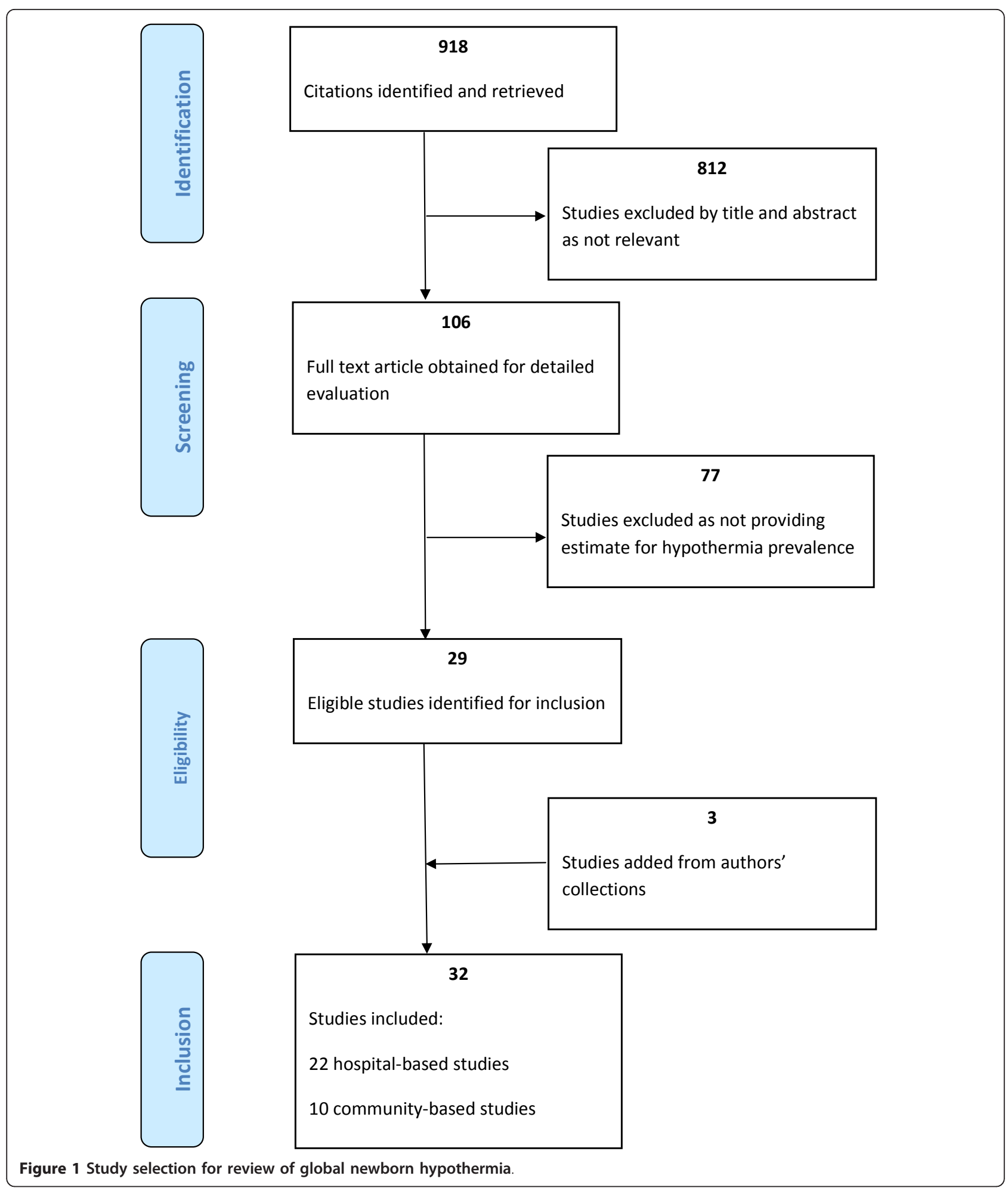

inclusion into the review: those specifying study location, setting (hospital or community based), sample size, case definition of body temperature for hypothermia, temperature measurement method, and point estimates for hypothermia prevalence. For each identified reference, full-text copies were obtained. Additional references were sought from these articles' reference lists and from additional collection of the authors. We reviewed each 
pertinent paper in detail and used a systematic coding form to summarize each study's quality measures and further key findings.

\section{Results}

The prevalence of neonatal hypothermia globally

Newborn hypothermia is ubiquitous, including tropical environments. As summarized in Table 1 by World Health Organization (WHO) region and study setting, we found a total of 31 studies reporting body temperatures in newborns. While 21 studies reporting on hypothermia prevalence were hospital based, we identified 10 community-based studies from Southeast Asia. Three studies from Sarlahi, Nepal, reported hypothermia data on an identical study population [16-18].

These, and an earlier community-based study from Nepal [19], found newborn hypothermia to be almost universal at birth. Overall in community-based studies (all conducted in Nepal or India), hypothermia prevalence ranged from $11 \%$ to $92 \%$. Perhaps not surprisingly, lower ambient temperatures $[20,21]$ and cold season [22] were associated with a higher incidence of hypothermia in Indian studies.

However, not only in climatic regions perceived as high risk for hypothermia such as the hills and mountains of Nepal, Northern India, Bangladesh, Pakistan and Bhutan [22] do infants get too cold. Hypothermia is a problem even in tropical countries and warm climates, as was first reported more than fifty years ago [23]. A classic study from Dakar, Senegal found only 5 in 78 babies with a temperature over $36^{\circ} \mathrm{C}$ [24]. All identified studies from Africa to date are hospital based, report poor newborn practices and high prevalences of newborn hypothermia ranging from $44 \%$ to $69 \%$ in Zambia $[25,26]$ to $53 \%$ in Ethiopia [27], $62 \%$ to $68 \%$ in Nigeria [28], and $85 \%$ in Zimbabwe [29]. Large studies from other countries confirm the global tendency for newborn hypothermia in different climate conditions, from Asia (China) (cited in [30]), [31], the Middle East (Iran) [32,33] and South America (Brazil) [34].

\section{Discussion}

Overall, the prevalence of hypothermia in hospital-based studies ranges from 32 to $85 \%$, with the exception of a low outlier (8\% in Guinea Bissau [35]). This wide range might in part be attributable to the varying case definition of hypothermia across studies, ranging from $35.0^{\circ} \mathrm{C}$ to $36.5^{\circ} \mathrm{C}$, and in part to the climatic environment and its seasonal variations discussed below.

We caution that the direct comparability of prevalence data from these hospital-based studies are limited by selection bias, as study populations often represent a high-risk patient cohort and might not be representative of the local population. Data comparability is further limited by the heterogeneity in case definition of hypothermia, which ranges from as low as $35.0^{\circ} \mathrm{C}$ to the current WHO standard of $36.5^{\circ} \mathrm{C}$ body temperature, measured with homogeneously temperature measurement methods across studies. Furthermore, prevalence data are confounded by various covariates inconsistently present across studies, such as environmental temperatures and seasonality, the newborns' maturity and age, or maternal factors.

\section{Risk factors for hypothermia}

Various studies identified several risk factors for newborn hypothermia, which we categorize as follows.

\section{Environmental}

Termed 'contextual' by other authors [36]; initially, an infant's body temperature is associated with maternal temperatures [37]. Several studies have confirmed the intuitive association with environmental temperatures and with the cold seasons. The Gadchiroli trial, with an overall hypothermia prevalence of $17 \%$, showed variations from summer $(14.8 \%)$ to winter $(21.5 \%)$ [21,38]. Other studies from Haryana in Northern India recorded an overall hypothermia prevalence of $11 \%$, ranging from $3 \%$ in the summer to $19 \%$ in winter [20]. In Uttar Pradesh, hypothermia was detected in $14 \%(\mathrm{n}=148)$ and was found to strongly correlate with environmental temperature [39]. Another study from the same state found a higher rate of $45 \%$, which likewise was correlated with environmental temperatures and varied considerably over the seasons, ranging from $70 \%$ during winter to $20 \%$ during summer [22]. Studies from Nepal suggest that the higher prevalence of hypothermia in hospitals during winter months can successfully be addressed through staff training of early drying, wrapping, and breastfeeding $[40,41]$. The Sarlahi trial found that while even in the hottest season of the year almost one-fifth of infants were hypothermic [16], the risk of moderate-to-severe hypothermia further increased by $41 \%$ for each $5^{\circ} \mathrm{C}$ decrease in ambient temperature [17].

\section{Physiological}

While newborns of all gestational ages are at risk of losing body heat after birth, premature and small babies are particularly vulnerable due to their physiologic disadvantages. A newborn's thermal regulatory mechanisms are highly sophisticated, but particularly in babies born prematurely easily overwhelmed [7]. Neonatal anatomic characteristics add to the metabolic burden of increased energy requirements: term babies have a 2.7 times greater body surface and preterm babies an up to 4.0 times greater surface per weight than adults.

Several conditions of immature thermal regulation, such as LBW, prematurity, intrauterine growth restriction, and asphyxia (with heat loss due to lack of oxygenation and, where attempted, during reanimation efforts) during birth are significantly associated with an abnormal low body temperature $[31,32,40,42,43]$. Hypoglycemia is an important contributor to hypothermia [44], and vice versa: it 
Table 1 Global epidemiology of newborn hypothermia

\begin{tabular}{|c|c|c|c|c|c|c|c|}
\hline Reference & Location & Setting & $\mathrm{N}$ & $\begin{array}{l}\text { Case } \\
\text { definition } \\
\text { body } \\
\text { temp }\end{array}$ & $\begin{array}{l}\text { Temperature } \\
\text { measurements }\end{array}$ & $\begin{array}{l}\text { Hypothermia } \\
\text { prevalence }\end{array}$ & Additional findings \\
\hline \multicolumn{8}{|l|}{ Africa } \\
\hline \multicolumn{8}{|c|}{ Hospital based: } \\
\hline$[28]$ & $\begin{array}{l}\text { Sagamu, } \\
\text { Nigeria }\end{array}$ & $\begin{array}{l}\text { University } \\
\text { Hospital }\end{array}$ & 150 & $<36.5^{\circ} \mathrm{C}$ & $\begin{array}{l}\text { Axillary upon } \\
\text { admission }\end{array}$ & $62 \%$ & $\begin{array}{l}\text { Hypothermia risk highest in the first } 24 \\
\mathrm{~h} \text { of life in preterm babies }\end{array}$ \\
\hline [75] & $\begin{array}{l}\text { Sagamu, } \\
\text { Nigeria }\end{array}$ & $\begin{array}{l}\text { University } \\
\text { Hospital }\end{array}$ & 111 & $<36.5^{\circ} \mathrm{C}$ & $\begin{array}{l}\text { Axillary upon } \\
\text { admission }\end{array}$ & $68 \%$ & $\begin{array}{l}\text { Hypothermia risk highest in low birth } \\
\text { weight babies and those who were not } \\
\text { breastfed }\end{array}$ \\
\hline [76] & $\begin{array}{l}\text { Ibadan, } \\
\text { Nigeria }\end{array}$ & $\begin{array}{l}\text { University } \\
\text { Hospital }\end{array}$ & 541 & $<35.0^{\circ} \mathrm{C}$ & N/A & $45 \%$ & $\begin{array}{l}\text { Hypothermia more prevalent on } \\
\text { admission in infants born outside the } \\
\text { hospital than those born at the hospital }\end{array}$ \\
\hline [35] & $\begin{array}{l}\text { Guinea- } \\
\text { Bissau }\end{array}$ & $\begin{array}{l}\text { National } \\
\text { Hospital }\end{array}$ & 2,926 & $<34.5^{\circ} \mathrm{C}$ & $\begin{array}{l}\text { Axillary within } 12 \mathrm{~h} \\
\text { of birth }\end{array}$ & $8 \%$ & $\begin{array}{l}\text { Hypothermia of }<34.5^{\circ} \mathrm{C} \text { associated with } \\
\text { mortality risk of } 4.81(95 \% \mathrm{Cl} 2.90 \text { to } \\
8.00) \text { in first } 7 \text { days compared to those } \\
\text { without hypothermia }\end{array}$ \\
\hline [29] & $\begin{array}{l}\text { Kampala, } \\
\text { Uganda }\end{array}$ & $\begin{array}{l}\text { Periurban } \\
\text { Hospital }\end{array}$ & 300 & $<36.5^{\circ} \mathrm{C}$ & $\begin{array}{l}\text { Rectal and tympanic } \\
\text { four times within } 90 \\
\text { minutes postpartum }\end{array}$ & $79 \%$ & $\begin{array}{l}\text { Hypothermia incidence increased from } \\
29 \% \text { at } 10 \text { minutes postpartum to } 79 \% \\
\text { at } 90 \text { minutes postpartum }\end{array}$ \\
\hline [47] & $\begin{array}{l}\text { Kampala, } \\
\text { Uganda }\end{array}$ & $\begin{array}{l}\text { Periurban } \\
\text { Hospital }\end{array}$ & 249 & $<36.5^{\circ} \mathrm{C}$ & $\begin{array}{l}\text { Rectal } 60 \text { minutes } \\
\text { postpartum }\end{array}$ & $46 \%$ & $\begin{array}{l}\text { Early bathing increased the risk of } \\
\text { hypothermia in spite of use of warm } \\
\text { water and skin-to-skin care }\end{array}$ \\
\hline [25] & $\begin{array}{l}\text { Lusaka, } \\
\text { Zambia }\end{array}$ & $\begin{array}{l}\text { University } \\
\text { Hospital }\end{array}$ & 62 & $<36.0^{\circ} \mathrm{C}$ & $\begin{array}{l}\text { Rectal } 30 \text { and } 120 \\
\text { minutes after } \\
\text { delivery }\end{array}$ & $53 \%$ and $69 \%$ & $\begin{array}{l}\text { At discharge after an average of } 14 \mathrm{~h} \text {, } \\
\text { hypothermia was still persistent in half } \\
\text { of all babies sampled }\end{array}$ \\
\hline [26] & $\begin{array}{l}\text { Lusaka, } \\
\text { Zambia }\end{array}$ & $\begin{array}{l}\text { University } \\
\text { Hospital }\end{array}$ & 261 & $<36.0^{\circ} \mathrm{C}$ & $\begin{array}{l}\text { Rectal upon } \\
\text { admission }\end{array}$ & $44 \%$ & $\begin{array}{l}\text { Mortality was higher in hypothermic } \\
\text { infants than in those who were not } \\
\text { hypothermic }\end{array}$ \\
\hline [77] & $\begin{array}{l}\text { Harare, } \\
\text { Zimbabwe }\end{array}$ & $\begin{array}{l}\text { University } \\
\text { Hospital }\end{array}$ & 313 & $<36.0^{\circ} \mathrm{C}$ & Axillary & $51.4 \%$ & \\
\hline [59] & $\begin{array}{l}\text { Harare, } \\
\text { Zimbabwe }\end{array}$ & $\begin{array}{l}\text { University } \\
\text { Hospital }\end{array}$ & 313 & $<36.0^{\circ} \mathrm{C}$ & $\begin{array}{l}\text { Axillary upon } \\
\text { admission }\end{array}$ & $85 \%$ & \\
\hline [27] & Ethiopia & Hospital & & $<36.0^{\circ} \mathrm{C}$ & N/A & $53 \%$ & \\
\hline \multicolumn{8}{|l|}{ Asia } \\
\hline \multicolumn{8}{|c|}{ Hospital based: } \\
\hline [78] & $\begin{array}{l}\text { Iran, } \\
\text { different } \\
\text { provinces }\end{array}$ & $\begin{array}{l}\text { University } \\
\text { Hospitals }\end{array}$ & 1,952 & $<36.0^{\circ} \mathrm{C}$ & $\begin{array}{l}\text { Rectal after delivery } \\
\text { and four repeats } \\
\text { within } 6 \mathrm{~h} \text { of } \\
\text { admission to } \\
\text { neonatal unit }\end{array}$ & $33.8 \%$ & $\begin{array}{l}\text { Newborn with low birth weight, } \\
\text { prematurity, low Apgar scores, of } \\
\text { multiple pregnancies and after } \\
\text { cardiopulmonary resuscitation at higher } \\
\text { risk for being hypothermic in regression } \\
\text { analysis. Hypothermia is associated with } \\
\text { an increased risk of neonatal mortality } \\
\text { risk (OR }=3.1,95 \% \mathrm{Cl} 1.9 \text { to } 5.2) \text { as well } \\
\text { as risk of metabolic acidosis, jaundice, } \\
\text { respiratory distress, hypoglycemia, and } \\
\text { pulmonary hemorrhage. }\end{array}$ \\
\hline [33] & Tehran, Iran & $\begin{array}{l}\text { University } \\
\text { Hospitals }\end{array}$ & 940 & $<36.5^{\circ} \mathrm{C}$ & $\begin{array}{l}\text { Rectal upon } \\
\text { admission to } \\
\text { neonatal unit (mean } \\
\text { time after delivery } 20 \\
\text { minutes) }\end{array}$ & $53.5 \%$ & $\begin{array}{l}\text { Hypothermia at birth is associated with } \\
\text { an increased neonatal mortality risk (OR } \\
=3.64,95 \% \mathrm{Cl} 1.85 \text { to } 7.18) \text {, as well as } \\
\text { risk for respiratory distress (OR }=2.12 \text {, } \\
95 \% \mathrm{Cl} 1.53 \text { to } 2.93) \text {, metabolic acidosis } \\
(\mathrm{OR}=2.83,95 \% \mathrm{Cl} 1.74 \text { to } 4.59) \text {, and } \\
\text { jaundice (OR }=2.01,95 \% \mathrm{Cl} 1.45 \text { to } \\
\text { 2.79), controlling for weight and } \\
\text { gestational age }\end{array}$ \\
\hline [32] & Tehran, Iran & $\begin{array}{l}\text { University } \\
\text { Hospital }\end{array}$ & 900 & $<36.5^{\circ} \mathrm{C}$ & $\begin{array}{l}\text { Rectal after delivery } \\
\text { and four repeats } \\
\text { within } 6 \mathrm{~h} \text { of } \\
\text { admission to } \\
\text { neonatal unit }\end{array}$ & $53.3 \%$ & $\begin{array}{l}\text { Low birth weight, low gestational, age } \\
\text { environmental temperature, low Apgar } \\
\text { score, multiple pregnancy and receiving } \\
\text { cardiopulmonary resuscitation increased } \\
\text { risk for being hypothermic in regression } \\
\text { analysis }\end{array}$ \\
\hline
\end{tabular}


Table 1 Global epidemiology of newborn hypothermia (Continued)

\begin{tabular}{|c|c|c|c|c|c|c|c|}
\hline [79] & $\begin{array}{l}\text { Hangzhou, } \\
\text { China }\end{array}$ & $\begin{array}{l}\text { University } \\
\text { Hospital }\end{array}$ & 200 & $<36.5^{\circ} \mathrm{C}$ & $\begin{array}{l}\text { Axillary after delivery } \\
\text { and five times on } \\
\text { first, second and } \\
\text { third day }\end{array}$ & $52 \%$ & $\begin{array}{l}\text { Hypothermia risk associated with low } \\
\text { birth weight and gestational age }\end{array}$ \\
\hline [40] & $\begin{array}{l}\text { Kathmandu, } \\
\text { Nepal }\end{array}$ & $\begin{array}{l}\text { Maternity } \\
\text { Hospital }\end{array}$ & 495 & $<36.0^{\circ} \mathrm{C}$ & $\begin{array}{l}\text { Rectal } 2 \mathrm{~h} \text { after } \\
\text { delivery }\end{array}$ & $85 \%$ & \\
\hline [80] & $\begin{array}{l}\text { Kathmandu, } \\
\text { Nepal }\end{array}$ & $\begin{array}{l}\text { Maternity } \\
\text { Hospital }\end{array}$ & 82 & $<35.0^{\circ} \mathrm{C}$ & Rectal after delivery & $26 \%$ & \\
\hline [60] & $\begin{array}{l}\text { Kathmandu, } \\
\text { Nepal }\end{array}$ & $\begin{array}{l}\text { Maternity } \\
\text { Hospital }\end{array}$ & 100 & $<36.0^{\circ} \mathrm{C}$ & Rectal after delivery & $64 \%$ & $\begin{array}{l}16 \% \text { of hypothermic infants died within } \\
\text { first week of life }\end{array}$ \\
\hline [81] & $\begin{array}{l}\text { Kathmandu, } \\
\text { Nepal }\end{array}$ & $\begin{array}{l}\text { Maternity } \\
\text { Hospital }\end{array}$ & 76 & $<36.0^{\circ} \mathrm{C}$ & Axillary after delivery & $63 \%$ & \\
\hline [82] & $\begin{array}{l}\text { Kathmandu, } \\
\text { Nepal }\end{array}$ & $\begin{array}{l}\text { Maternity } \\
\text { Hospital }\end{array}$ & 35 & $<36.0^{\circ} \mathrm{C}$ & $\begin{array}{l}\text { Continuous axillary } \\
\text { and forehead skin } \\
\text { probe }\end{array}$ & $\begin{array}{l}72 \% \text { (Incidence in } \\
\text { percent of time } \\
\text { being hypothermic } \\
\text { from birth to } 8 \mathrm{~h} \text { of } \\
\text { life) }\end{array}$ & \\
\hline [83] & $\begin{array}{l}\text { Mumbai, } \\
\text { India }\end{array}$ & Hospital & 206 & N/A & N/A & $37 \%$ & $\begin{array}{l}\text { Prevalence } 5.9 \% \text { in infants with } \\
\text { kangaroo mother care }\end{array}$ \\
\hline \multicolumn{8}{|l|}{ Asia } \\
\hline \multicolumn{8}{|c|}{ Community based: } \\
\hline [19] & $\begin{array}{l}\text { Kathmandu, } \\
\text { Nepal }\end{array}$ & Community & 12 & $<35.0^{\circ} \mathrm{C}$ & $\begin{array}{l}\text { Rectal within } 12 \mathrm{~h} \\
\text { after delivery }\end{array}$ & $91 \%$ & \\
\hline [84] & $\begin{array}{l}\text { Kathmandu, } \\
\text { Nepal }\end{array}$ & Community & 250 & $<36.0^{\circ} \mathrm{C}$ & Axillary & $82 \%$ & \\
\hline [20] & $\begin{array}{l}\text { Haryana, } \\
\text { India }\end{array}$ & Community & 189 & $<35.6^{\circ} \mathrm{C}$ & $\begin{array}{l}\text { Axillary once on first } \\
\text { day }\end{array}$ & $11 \%$ & $\begin{array}{l}\text { Higher prevalence in winter (19\%) than } \\
\text { in summer (3\%); in a secondary analysis } \\
\text { applying a case definition of } 36.5^{\circ} \mathrm{C} \text {, } \\
\text { prevalence was } 38 \% \text {; correlation } \\
\text { between room air temperature and } \\
\text { body temperature }\end{array}$ \\
\hline [21] & Gadchiroli & Community & 763 & $<35.0^{\circ} \mathrm{C}$ & $\begin{array}{l}\text { Axillary on } 8 \text { days } \\
\text { during first month }\end{array}$ & $17 \%$ & $\begin{array}{l}\text { Higher prevalence in winter than in } \\
\text { summer }\end{array}$ \\
\hline [22] & $\begin{array}{l}\text { Uttar } \\
\text { Pradesh, } \\
\text { India }\end{array}$ & Community & 1,732 & $<36.5^{\circ} \mathrm{C}$ & $\begin{array}{l}\text { Axillary } 3 \text { to } 36 \mathrm{~h} \\
\text { after birth }\end{array}$ & $43 \%$ & $\begin{array}{l}\text { Body temperature lower in low ambient } \\
\text { temp }<20^{\circ} \mathrm{C} \text { and in newborns with } \\
\text { hypothermic mothers }\end{array}$ \\
\hline [85] & Dehli, India & Community & 32 & $<35.0^{\circ} \mathrm{C}$ & $\begin{array}{l}\text { Axillary daily on first } \\
7 \text { days of life }\end{array}$ & $25 \%$ & \\
\hline [39] & $\begin{array}{l}\text { Uttar } \\
\text { Pradesh, } \\
\text { India }\end{array}$ & Community & 148 & $<36.5^{\circ} \mathrm{C}$ & $\begin{array}{l}\text { Axillary within } 48 \mathrm{~h} \\
\text { and on days } 7,30 \\
\text { and } 60\end{array}$ & $14 \%$ & \\
\hline [16] & $\begin{array}{l}\text { Sarlahi, } \\
\text { Nepal }\end{array}$ & Community & 23,240 & $<36.5^{\circ} \mathrm{C}$ & $\begin{array}{l}\text { Axillary on } 10 \text { days } \\
\text { during first month }\end{array}$ & $92.3 \%$ & $\begin{array}{l}\text { Hypothermia risk highest in the first } 72 \\
\mathrm{~h} \text { of life }\end{array}$ \\
\hline [17] & $\begin{array}{l}\text { Sarlahi, } \\
\text { Nepal }\end{array}$ & Community & 23,240 & $<36.5^{\circ} \mathrm{C}$ & $\begin{array}{l}\text { Axillary on } 10 \text { days } \\
\text { during first month }\end{array}$ & $92.3 \%$ & $\begin{array}{l}\text { Hypothermia risk highest in preterm } \\
\text { babies, females, those breastfed later } \\
\text { than } 24 \mathrm{~h} \text { after delivery, and those with } \\
\text { hypothermic mothers }\end{array}$ \\
\hline [18] & $\begin{array}{l}\text { Sarlahi, } \\
\text { Nepal }\end{array}$ & Community & 23,240 & $<36.5^{\circ} \mathrm{C}$ & $\begin{array}{l}\text { Axillary on } 10 \text { days } \\
\text { during first month }\end{array}$ & $92.3 \%$ & $\begin{array}{l}\text { Mortality risk increases by } 80 \% \text { for every } \\
1^{\circ} \mathrm{C} \text { decrease. Mortality risk } 6.11 \text { for } \\
\text { newborns }<35.0^{\circ} \mathrm{C} \text { compared to those } \\
>36.5^{\circ} \mathrm{C} \text {. }\end{array}$ \\
\hline \multicolumn{8}{|c|}{ South America } \\
\hline \multicolumn{8}{|c|}{ Hospital based: } \\
\hline [34] & Recife, Brazil & $\begin{array}{l}\text { University } \\
\text { Hospital }\end{array}$ & 320 & $<36.5^{\circ} \mathrm{C}$ & Axillary on admission & $32 \%$ & $\begin{array}{l}\text { Hypothermia increased neonatal } \\
\text { mortality risk, } \mathrm{AOR}=3.49,95 \% \mathrm{Cl} 3.18 \text { to } \\
3.81\end{array}$ \\
\hline
\end{tabular}


maintains a vicious circle, which leads to feeding weakness, weight loss and finally increased mortality, which first was shown in studies in the 1950s and 1960s [45]. Breastfeeding therefore treats hypothermia not only through bonding with and warming through the mother, but also by replenishing a newborn's glucose levels.

\section{Behavioral}

Early bathing contributes significantly to heat loss and increases the incidence of hypothermia in cold climates [46] and even in a warm environment [47] and should be postponed until at least after the first $6 \mathrm{~h}$ of life, and possibly longer. It is, however, a widespread practice even in high-risk environments [48-51].

Massage and oil applications to clean the child early after birth continue to be a widespread tradition [40]. Evidence for the influence of massage and oil application on hypothermia is contradictory. While suggesting protection from hypothermia [40] and against nosocomial infections in preterm very low birth weight infants [52], it has also been shown in other studies to have detrimental effects on the skin as a protective barrier [53] and to lead to heat loss [54].

\section{Socioeconomic factors}

An infant's low body temperature is also associated with having a young and inexperienced mother, coming from a family with low socioeconomic status [55], or being born to a mother who already had multiple births [32].

While some of these physiologic risk factors have been documented decades ago, awareness of the risks associated with hypothermia, as indicated in a multinational survey [56] and another one from India [57], indicating that healthcare professionals have limited knowledge of the diagnosis and management of newborn hypothermia. Facilities in resource-limited environments rarely have sufficient capacity to address thermal protection. In a recent study in Zambia, we found that health centers are not well prepared to provide thermal protection, with only very few equipped with heat control for the delivery room $(7 \%)$ or a neonatal warmer (9\%) [58].

\section{Associations of hypothermia with newborn morbidity and mortality}

Several studies investigated the association between neonatal hypothermia and associated mortality risks. In our review, case fatality rates (CFR) for newborn hypothermia globally range from $8.5 \%$ to $52 \%[21,26,34,59,60]$. A study from India that included only hypothermic babies specifically investigated morbidities and mortalities and found CFRs that ranged from $39.3 \%$ for mild hypothermia to $80 \%$ for severe hypothermia. This study demonstrated a dramatic effect of comorbidities and confirmed that hypothermia has a much worse outcome when associated with other newborn problems. Fatality rates increased to
$71.4 \%$ with hypoglycemia, $83.3 \%$ with hypoxia, and $90.9 \%$ with shock [61].

However, the above-cited studies do not sufficiently control for potential confounders of the effect of hypothermia on mortality and thus provide implausibly high CFRs in the context of high hypothermia prevalence particularly in community settings. Furthermore, these studies reflect the higher risk of hospital populations selected for these studies, and their CFRs are therefore not applicable to community settings. Yet, hypothermia has been shown to be associated with mortality in a community setting. A community-based study conducted in Sarlahi, Nepal found that mortality increased by approximately $80 \%$ for every degree Celsius decrease in first observed axillary temperature and that relative risk of death ranged from 2 to 30 times within the current WHO classification for moderate hypothermia, increasing with greater severity of hypothermia [18].

The evidence on the effect of thermal protection on morbidity and mortality is currently limited. Skin-to-skin care has been shown to substantially reduce neonatal mortality among preterm infants born in facilities [62], but its effectiveness for infants born at term and in communities is less clear. In Zambia, we recently showed that training traditional birth attendants in newborn care emphasizing simple thermal protection (wiping the newborn dry and wrapping the dried infant in a separate piece of cloth), along with resuscitation and early treatment of possible sepsis where indicated, reduced mortality rates at day 28 after birth by $45 \%$ [63].

Whether wrapping the newborn in plastic (polyethylene or vinyl) bags is sufficient for thermal protection in low birth weight and premature infants remains controversial. While one recent study failed to show an effect of wrapping on hypothermia rates [64], others found that this approach effectively raised body temperature $[65,66]$ and did so more quickly than radiant heaters $[67,68]$, however did not reduce mortality [69].

\section{Rethinking and redefining neonatal hypothermia}

Our and other reviews [36,70] suggest that the burden of hypothermia is still highly prevalent including in tropical countries, practices contributing to heat loss in the newborn are still deeply rooted in many cultures and are difficult to change, technologies adapted to resource-poor environments are still at a developmental stage, simple thermoprotective interventions and behaviors are insufficiently practiced, providers and caretakers lack an understanding of the problem, and adverse health outcomes continue to take their toll in morbidity and mortality in newborns. There is thus a critical need for researchers and policy makers to take on the challenge of newborn 
hypothermia and address it within a larger framework of maternal and child health programs.

Qualitative studies from Africa and South Asia suggest that delivery and newborn care practices contributing to heat loss are still common globally. Various cultural and sometimes economic barriers often interfere with implementing simple steps to prevent hypothermia. Heating the birth place is costly for families in resource-poor countries [51], and drying and wrapping the baby is often not a priority when the mother needs attention after delivery [50]. In Ghana, for example, the practice of bathing newborns immediately after delivery is sometimes rooted in concerns about 'ritual pollution' [71] or the belief of helping the baby sleep and feel clean, and reducing body odor in later life; attitudes that informants felt would be difficult to change [72] and which need to be taken into account when programming for behavior change.

\section{Major gaps in our understanding of neonatal hypothermia}

Since in most parts of the world temperature is not measured and recorded in most newborns immediately after birth, the epidemiological picture of hypothermia and its clinical consequences is yet incomplete. Hypothermia is believed to be a common problem not only in developing countries, but also in formerly socialist countries [56]. There are few studies from current lower-middle-income countries.

To the best of our knowledge, no population risk attributable to hypothermia has been published yet. There is no consistent definition of normal newborn body temperature, and consequently data that would allow for pooled risk estimates for newborn hypothermia are still incomplete. Temperatures have been shown to vary widely in healthy newborns [73], and standard medical textbooks disagree on the lower normal limit, ranging from 35.5 to $36.5^{\circ} \mathrm{C}$, as well as the normal upper level, citing values from 37.0 to $37.9^{\circ} \mathrm{C}$ [74].

Standard randomized controlled trials to define temperature thresholds associated with adverse health effects (morbidity as well as mortality) and to quantify the contribution of hypothermia to neonatal mortality as specific cause of death have not been conducted. In fact, those studies might be methodologically impossible to undertake, or at least ethically problematic, because the detection of hypothermia prompts therapeutic intervention and thus artificially reduces the associated mortality risk.

Given these limitations, standard measurements of body temperature could be included in newborn studies to complement available epidemiologic data. Newborn trials conducted for other reasons that include data on newborn body temperature could facilitate further investigation of the association of newborn hypothermia with morbidities and disease-specific mortalities. Axillary measurements with standard digital thermometers are inexpensive and can easily be incorporated into most newborn care clinical guidelines and study protocols.

Currently, the best available data come from trials with hypothermia-unrelated interventions providing temperature data, such as the Sarlahi trial in Nepal [18]. Further studies on the mortality and morbidity risks posed by newborn hypothermia are warranted, particularly in subSaharan Africa, to refine the current WHO classification scheme for hypothermia that, as has been suggested, might have to revised into narrower categories to more appropriately reflect the overall mortality-hypothermia risk relationship [18,70].

Further research is needed to understand the magnitude and perception of the problem as well as the feasibility and effectiveness of thermoprotective interventions for newborn morbidity and mortality. Methodologically sound hospital-based and community-based studies are required to understand the problem in sub-Saharan Africa specifically. These studies will ideally include potential confounders and mediating factors that have largely not been adequately addressed so far, such as maternal temperature, environmental conditions, and sociocultural contexts and their association with newborn hypothermia.

Various international neonatal advocacy alliances have included thermoprotection strategies in their newborn health programming, including the Healthy Newborn Partnership (Save the Children), Partnership for Safe Motherhood and Newborn Health (WHO), and the Child Survival Partnership (UNICEF). Nevertheless, hypothermia remains a major challenge for newborn survival. Globally, progress has been particularly slow in improving survival in infants less than 7 days old [10]. This might be attributable to the delivery gap in developing countries for interventions addressing early causes of death such as preterm birth and asphyxia, both of which have worse outcomes in the presence of hypothermia.

More than a quarter of a century ago, a study from Senegal reported: 'Deaths [from hypothermia] seem easy to avoid. Purchasing blankets, putting the newborn babies with their mother and not in cots, prohibiting unnecessary washing of the babies, and supplying maternity hospitals with solar water heaters are all easy steps which could greatly reduce this problem. These improvements are gradually being introduced in the maternity hospital we surveyed though it is proving very difficult to persuade elderly auxiliary midwives not to remove the vernix caseosa by thorough washing, this being part of a strong tradition. Health workers in dispensaries should also be aware of the problem of neonatal hypothermia. We frequently see at our clinic mothers with young infants whose growth seems unsatisfactory. They usually complain about not having enough milk. If the infant is lightly clothed and his rectal temperature is well below 
normal, he may be expending too much energy on thermogenesis. Advising such mothers to use warmer clothing for their babies is usually enough to make them put on weight. Artificial feeding would be wholly inappropriate in such conditions and could even prove fatal' [24]. As our review suggests, most of these statements and easy remedies still hold true today in most of the world.

\section{Conclusions}

Although hypothermia is a direct cause of death only in a small proportion of newborn mortality, it is closely associated with mortality from common causes of newborn deaths such as severe infections, prematurity, and asphyxia. Neonatal deaths mostly occur at home in lowincome countries with weak health systems, where the perception of hypothermia as a risk to the newborn is currently insufficient even among health professionals.

Improvement of practices and services, even (and particularly) where health systems are weak, must focus on the poorest, highest-mortality countries, and on the time of greatest risk: birth and the first days of life. MDG 4 can only be met with a significant decrease in neonatal mortality. We propose that understanding, managing, and significantly mitigating the global burden of hypothermia, a largely understudied risk factor for neonatal survival, might be relatively simple and contribute substantially towards reaching MDG 4.

\section{Abbreviations}

CFR: case fatality rates; LBW: low birth weight; MDG: Millennium Development Goal; WHO: World Health Organization.

\section{Authors' contributions \\ $\mathrm{KL}$ and DTJ designed the study. $\mathrm{KL}, \mathrm{DEB}$, and $\mathrm{DHH}$ conceived the search protocol. All authors contributed to the analysis and interpretation of data. $\mathrm{KL}$ drafted the manuscript. All authors revised it critically for important intellectual content, and have given final approval of the version to be published.}

\section{Competing interests}

The authors declare that they have no competing interests.

\section{Author details}

'Boston University School of Medicine, 801 Massachusetts Avenue, Crosstown 2077, Boston, Massachusetts 02118, USA. ²Department of Global Health and Population, 665 Huntington Avenue, Building I 12th Floor, Boston, Massachusetts 02115, USA. ${ }^{3}$ Department of Global Health, University of Washington, 325 9th Avenue, Ste. 359931, Seattle, WA 98104, USA.

${ }^{4}$ Department of International Health and Medicine, Boston University Schools of Public Health and Medicine, 801 Massachusetts Avenue, Boston,

Massachusetts 02118, USA. ${ }^{5}$ Zambia Centre for Applied Health Research and Development, 4649 Beit Road, Lusaka, Zambia.

Received: 13 April 2012 Accepted: 31 January 2013

Published: 31 January 2013

\section{References}

1. Murray CJ, Laakso T, Shibuya K, Hill K, Lopez AD: Can we achieve Millennium Development Goal 4? New analysis of country trends and forecasts of under-5 mortality to 2015. Lancet 2007, 370:1040-1054.
2. UNICEF: Levels \& Trends in Child Mortality, Estimates Developed by the UN Inter-agency Group for Child Mortality Estimation, Report 2010. [http://www.childinfo.org/files/Child_Mortality_Report_2010.pdf].

3. Black RE, Cousens S, Johnson HL, Lawn JE, Rudan I, Bassani DG, Jha P, Campbell H, Walker CF, Cibulskis R, Eisele T, Li L, Mather C: Global, regional, and national causes of child mortality in 2008: a systematic analysis. Lancet 2010, 375:1969-1987.

4. Rajaratnam JK, Marcus JR, Flaxman AD, Wang H, Levin-Rector A, Dwyer L, Costa M, Lopez AD, Murray CJ: Neonatal, postneonatal, childhood, and under-5 mortality for 187 countries, 1970-2010: a systematic analysis of progress towards Millennium Development Goal 4. Lancet 2010, 375:1988-2008.

5. Oestergaard MZ, Inoue M, Yoshida S, Mahanani WR, Gore FM, Cousens S, Lawn JE, Mathers CD: Neonatal mortality levels for 193 countries in 2009 with trends since 1990: a systematic analysis of progress, projections, and priorities. PLoS Med 2011, 8:e1001080.

6. Knobel $R$, Holditch-Davis D: Thermoregulation and heat loss prevention after birth and during neonatal intensive-care unit stabilization of extremely low-birthweight infants. J Obstet Gynecol Neonatal Nurs 2007, 36:280-287.

7. Lunze K, Hamer DH: Thermal protection of the newborn in resourcelimited environments. J Perinatol 2012, 32:317-324.

8. Sachdev HP: Commentary: utilizing information on causes of neonatal deaths in less-developed countries. Int J Epidemiol 2006, 35:718-719.

9. Lawn JE, Wilczynska-Ketende K, Cousens SN: Estimating the causes of 4 million neonatal deaths in the year 2000. Int J Epidemiol 2006, 35:706-718.

10. Lawn JE, Cousens S, Zupan J: 4 million neonatal deaths: when? Where? Why? Lancet 2005, 365:891-900.

11. The American Academy of Pediatrics: Textbook of Neonatal Resuscitation. 6 edition. Elk Grove, IL: American Academy of Pediatrics; 2011.

12. Singhal N, Niermeyer S: Neonatal resuscitation where resources are limited. Clin Perinatol 2006, 33:219-228, x-xi.

13. Zupan J, Aahman E: Perinatal Mortality for the Year 2000: Estimates Developed by WHO Geneva, Switzerland: World Health Organization; 2005.

14. Moher D, Liberati A, Tetzlaff J, Altman DG: Preferred reporting items for systematic reviews and meta-analyses: the PRISMA statement. PLoS Med 2009, 6:e1000097.

15. World Bank: Country and Lending Groups.[http://data.worldbank.org/ about/country-classifications/country-and-lending-groups].

16. Mullany LC, Katz J, Khatry SK, Leclerq SC, Darmstadt GL, Tielsch JM: Incidence and seasonality of hypothermia among newborns in southern Nepal. Arch Pediatr Adolesc Med 2010, 164:71-77.

17. Mullany LC, Katz J, Khatry SK, Leclerq SC, Darmstadt GL, Tielsch JM: Neonatal hypothermia and associated risk factors among newborns of southern Nepal. BMC Med 2010, 8:43.

18. Mullany LC, Katz J, Khatry SK, LeClerq SC, Darmstadt GL, Tielsch JM: Risk of mortality associated with neonatal hypothermia in southern Nepal. Arch Pediatr Adolesc Med 2010, 164:650-656.

19. Johanson RB, Rolfe P, Spencer SA, Rai R: Should thermometers be issued to birth attendants in Nepal? J Trop Pediatr 1992, 38:202.

20. Kumar R, Aggarwal AK: Body temperatures of home delivered newborns in north India. Trop Doct 1998, 28:134-136.

21. Bang AT, Reddy HM, Baitule SB, Deshmukh MD, Bang RA: The incidence of morbidities in a cohort of neonates in rural Gadchiroli, India: seasonal and temporal variation and a hypothesis about prevention. J Perinatol 2005, 25(Suppl 1):S18-28.

22. Darmstadt GL, Kumar $V$, Yadav R, Singh $V$, Singh $P$, Mohanty $S$, Baqui AH, Bharti N, Gupta S, Misra RP, Awasthi S, Singh JV, Santosham M: Introduction of community-based skin-to-skin care in rural Uttar Pradesh, India. J Perinatol 2006, 26:597-604.

23. Morley DC: Cold injury among children severely ill in the tropics. Lancet 1960, 2:1170-1171.

24. Briend A, de Schampheleire I: Neonatal hypothermia in West Africa. Lancet 1981, 1:846-847.

25. Christensson K, Ransjo-Arvidson AB, Kakoma C, Lungu F, Darkwah G, Chikamata D, Sterky G: Midwifery care routines and prevention of heat loss in the newborn: a study in Zambia. J Trop Pediatr 1988, 34:208-212.

26. Christensson K, Bhat GJ, Eriksson B, Shilalukey-Ngoma MP, Sterky G: The effect of routine hospital care on the health of hypothermic newborn infants in Zambia. J Trop Pediatr 1995, 41:210-214. 
27. Tafari N, Olsson EE: Neonatal cold injury in the tropics. Ethiop Med J 1973, 11:57-65.

28. Ogunlesi TA, Ogunfowora OB, Adekanmbi FA, Fetuga BM, Olanrewaju DM: Point-of-admission hypothermia among high-risk Nigerian newborns. BMC Pediatr 2008, 8:40.

29. Byaruhanga R, Bergstrom A, Okong P: Neonatal hypothermia in Uganda: prevalence and risk factors. J Trop Pediatr 2005, 51:212-215.

30. Tunell R: Hypothermia: epidemiology and prevention. In Improving Newborn Health in Developing Countries. Edited by: Costello A, Manandhar D. Hackensack, NJ; World Scientific Publishing Company; 2000:207-220.

31. Ji XC, Zhu CY, Pang RY: Epidemiological study on hypothermia in newborns. Chin Med J (Engl) 1993, 106:428-432.

32. Zayeri F, Kazemnejad A, Ganjali M, Babaei G, Nayeri F: Incidence and risk factors of neonatal hypothermia at referral hospitals in Tehran, Islamic Republic of Iran. East Mediterr Health J 2007, 13:1308-1318.

33. Nayeri F, Nili F: Hypothermia at birth and its associated complications in newborns: a follow up study. Iranian J Publ Health 2006, 35:5.

34. da Mota Silveira SM, Goncalves de Mello MJ, de Arruda Vidal S, de Frias PG, Cattaneo A: Hypothermia on admission: a risk factor for death in newborns referred to the Pernambuco Institute of Mother and Child Health. J Trop Pediatr 2003, 49:115-120.

35. Sodemann M, Nielsen J, Veirum J, Jakobsen MS, Biai S, Aaby P: Hypothermia of newborns is associated with excess mortality in the first 2 months of life in Guinea-Bissau, West Africa. Trop Med Int Health 2008, 13:980-986.

36. Kumar V, Shearer JC, Kumar A, Darmstadt GL: Neonatal hypothermia in low resource settings: a review. J Perinatol 2009, 29:401-412.

37. Knobel RB, Wimmer JE Jr, Holbert D: Heat loss prevention for preterm infants in the delivery room. J Perinatol 2005, 25:304-308.

38. Bang AT, Bang RA, Baitule S, Deshmukh M, Reddy MH: Burden of morbidities and the unmet need for health care in rural neonates-a prospective observational study in Gadchiroli, India. Indian Pediatr 2001, 38:952-965.

39. Agarwal S, Sethi V, Pandey RM, Kondal D: Human touch vs. axillary digital thermometry for detection of neonatal hypothermia at community level. J Trop Pediatr 2007, 54:2

40. Johanson RB, Spencer SA, Rolfe P, Jones P, Malla DS: Effect of post-delivery care on neonatal body temperature. Acta Paediatr 1992, 81:859-863.

41. Costello A, Manandhar D: Improving Newborn Infant Health in Developing Countries London, UK: Imperial College Press; 2000.

42. Goldsmith JR, Arbeli Y, Stone D: Preventability of neonatal cold injury and its contribution to neonatal mortality. Environ Health Perspect 1991, 94:55-59.

43. Mance MJ: Keeping infants warm: challenges of hypothermia. Adv Neonatal Care 2008, 8:6-12.

44. de Costello AML, Pal DK, Manandhar DS, Rajbhandari S, Land JM, Patel N: Neonatal hypoglycaemia in Nepal 2. Availability of alternative fuels. Arch Dis Child Fetal Neonatal Ed 2000, 82:F52-58.

45. Bell EF: Infant incubators and radiant warmers. Early Hum Dev 1983, 8:351-375

46. Johanson R, Richardson S, Spencer S, Rolfe P: Relative changes in neonatal body temperature: after birth and after a bath. Early Hum Dev 1989 26:230-231.

47. Bergstrom $A$, Byaruhanga $R$, Okong $P$ : The impact of newborn bathing on the prevalence of neonatal hypothermia in Uganda: a randomized, controlled trial. Acta Paediatr 2005, 94:1462-1467.

48. Iyengar SD, Bhakoo ON: Prevention of neonatal hypothermia in Himalayan villages. Role of the domiciliary caretaker. Trop Geogr Med 1991, 43:293-296.

49. Manandhar DS, Osrin D, Shrestha BP, Mesko N, Morrison J, Tumbahangphe KM, Tamang S, Thapa S, Shrestha D, Thapa B, Shrestha JR, Wade A, Borghi J, Standing H, Manandhar M, Costello AM: Effect of a participatory intervention with women's groups on birth outcomes in Nepal: cluster-randomised controlled trial. Lancet 2004, 364:970-979.

50. Osrin D, Tumbahangphe KM, Shrestha D, Mesko N, Shrestha BP, Manandhar MK, Standing H, Manandhar DS, Costello AM: Cross sectional, community based study of care of newborn infants in Nepal. BMJ 2002, 325:1063.

51. Sreeramareddy CT, Joshi HS, Sreekumaran BV, Giri S, Chuni N: Home delivery and newborn care practices among urban women in western Nepal: a questionnaire survey. BMC Pregnancy Childbirth 2006, 6:27.
52. Darmstadt GL, Saha SK, Ahmed AS, Chowdhury MA, Law PA, Ahmed S, Alam MA, Black RE, Santosham M: Effect of topical treatment with skin barrier-enhancing emollients on nosocomial infections in preterm infants in Bangladesh: a randomised controlled trial. Lancet 2005, 365:1039-1045.

53. Mullany LC, Darmstadt GL, Khatry SK, Tielsch JM: Traditional massage of newborns in Nepal: implications for trials of improved practice. J Trop Pediatr 2005, 51:82-86.

54. Cheah FC, Boo NY: Risk factors associated with neonatal hypothermia during cleaning of newborn infants in labour rooms. J Trop Pediatr 2000, 46:46-50.

55. Zabelle J, Dagan R, Neumann L, Sofer S: Risk factors for infantile hypothermia in early neonatal life. Pediatr Emerg Care 1990, 6:96-98.

56. Dragovich D, Tamburlini G, Alisjahbana A, Kambarami R, Karagulova J, Lincetto O, Malla DS, Mello MJ, Vani NS: Thermal control of the newborn: knowledge and practice of health professional in seven countries. Acta Paediatr 1997, 86:645-650.

57. Choudhary SP, Bajaj RK, Gupta RK: Knowledge, attitude and practices about neonatal hypothermia among medical and paramedical staff. Indian J Pediatr 2000, 67:491-496.

58. Hamer DH, Lunze K, Herlihy J, Mazimba A, Grogan C, Nkimberg M, Owens L, Yeboah-Antwi K, Semrau K: Prevention of neonatal hypothermia in Southern Province, Zambia. 61st Annual Meeting, American Society of Tropical Medicine and Hygiene, Nov 11-15, 2012, Atlanta, Georgia USA. Am J Trop Med Hyg 2012, 87(suppl):450.

59. Kambarami R, Chidede O: Neonatal hypothermia levels and risk factors for mortality in a tropical country. Cent Afr J Med 2003, 49:103-106.

60. Johanson RB, Malla DS, Tuladhar C, Amatya M, Spencer SA, Rolfe P: A survey of technology and temperature control on a neonatal unit in Kathmandu, Nepal. J Trop Pediatr 1993, 39:4-10.

61. Mathur NB, Krishnamurthy S, Mishra TK: Evaluation of WHO classification of hypothermia in sick extramural neonates as predictor of fatality. $J$ Trop Pediatr 2005, 51:341-345.

62. Lawn JE, Mwansa-Kambafwile J, Horta BL, Barros FC, Cousens S: 'Kangaroo mother care' to prevent neonatal deaths due to preterm birth complications. Int J Epidemiol 2010, 39(Suppl 1):144-154.

63. Gill CJ, Phiri-Mazala G, Guerina NG, Kasimba J, Mulenga C, MacLeod WB, Waitolo N, Knapp AB, Mirochnick M, Mazimba A, Fox MP, Sabin L, Seidenberg P, Simon $J$, Hamer DH: Effect of training traditional birth attendants on neonatal mortality (Lufwanyama Neonatal Survival Project): randomised controlled study. BMJ 2011, 342:d346.

64. Chitty HE, Kate Hodgson K, Thio M, Price R, Dawson J, Davis P: Wrapping is not sufficient to prevent hypothermia of preterm infants. Pediatric Academic Societies Annual Meeting 2012, Boston, MA

65. Chantaroj S, Techasatid W: Effect of polyethylene bag to prevent heat loss in preterm infants at birth: a randomized controlled trial. J Med Assoc Thai 2012, 94(Suppl 7):S32-37.

66. Lenclen R, Mazraani M, Jugie M, Couderc S, Hoenn E, Carbajal R, Blanc P, Paupe A: Use of a polyethylene bag: a way to improve the thermal environment of the premature newborn at the delivery room [in French]. Arch Pediatr 2002, 9:238-244.

67. Cardona Torres LM, Amador Licona N, Garcia Campos ML, GuizarMendoza JM: Polyethylene wrap for thermoregulation in the preterm infant: a randomized trial. Indian Pediatr 2011, 49:129-132.

68. Gathwala G, Singh G, Agrawal N: Safety and efficacy of vinyl bags in prevention of hypothermia of preterm neonates at birth. Indian J Public Health 54:24-26.

69. Reilly MC, Vohra S, Dunn M, Ferrelli K, Rac VE, Vincer M, Wimmer J, Zayack D, Soll R: The Vermont Oxford Network (VON) Heat Loss Prevention (HELP) Trial. Abstract E-PAS2012:2170.2. Pediatric Academic Societies Annual Meeting 2012, Boston, MA

70. Mullany LC: Neonatal hypothermia in low-resource settings. Semin Perinatol 2010, 34:426-433.

71. Thairu L, Pelto G: Newborn care practices in Pemba Island (Tanzania) and their implications for newborn health and survival. Matern Child Nutr 2008, 4:194-208

72. Hill Z, Tawiah-Agyemang C, Manu A, Okyere E, Kirkwood BR: Keeping newborns warm: beliefs, practices and potential for behaviour change in rural Ghana. Trop Med Int Health 2010, 15:1118-1124.

73. Fransson AL, Karlsson H, Nilsson K: Temperature variation in newborn babies: importance of physical contact with the mother. Arch Dis Child Fetal Neonatal Ed 2005, 90:F500-504. 
74. Takayama JI, Teng W, Uyemoto J, Newman TB, Pantell RH: Body temperature of newborns: what is normal? Clin Pediatr (Phila) 2000, 39:503-510.

75. Ogunlesi TA, Ogunfowora OB, Ogundeyi MM: Prevalence and risk factors for hypothermia on admission in Nigerian babies $<72 \mathrm{~h}$ of age. J Perinat Med 2009, 37:180-184.

76. Orimadegun AE, Akinbami FO, Tongo OO, Okereke JO: Comparison of neonates born outside and inside hospitals in a children emergency unit, southwest of Nigeria. Pediatr Emerg Care 2008, 24:354-358.

77. Kambarami R, Chidede O, Pereira N: ThermoSpot in the detection of neonatal hypothermia. Ann Trop Paediatr 2002, 22:219-223.

78. Zayeri F, Kazemnejad A, Ganjali M, Babaei G, Khanafshar N, Nayeri F: Hypothermia in Iranian newborns. Incidence, risk factors and related complications. Saudi Med J 2005, 26:1367-1371.

79. Li MX, Sun G, Neubauer H: Change in the body temperature of healthy term infant over the first 72 hours of life. J Zhejiang Univ Sci 2004, 5:486-493.

80. Johanson RB: Diagnosis of hypothermia-a simple test? J Trop Pediatr 1993, 39:313-314.

81. Manandhar N, Ellis M, Manandhar DS, Morley D, Costello AM: Liquid crystal thermometry for the detection of neonatal hypothermia in Nepal. J Trop Pediatr 1998, 44:15-17.

82. Ellis M, Manandhar N, Shakya U, Manandhar DS, Fawdry A, Costello AM: Postnatal hypothermia and cold stress among newborn infants in Nepal monitored by continuous ambulatory recording. Arch Dis Child Fetal Neonatal Ed 1996, 75:F42-45.

83. Suman RP, Udani R, Nanavati R: Kangaroo mother care for low birth weight infants: a randomized controlled trial. Indian Pediatr 2008, 45:17-23.

84. Ellis M, Manandhar D, Hunt $L$, Barnett $S$, Azad K: Touch detection of neonatal hypothermia in Nepal. Arch Dis Child Fetal Neonatal Ed 2006, 91: F367-368.

85. Green DA, Kumar A, Khanna R: Neonatal hypothermia detection by ThermoSpot in Indian urban slum dwellings. Arch Dis Child Fetal Neonatal Ed 2006, 91:F96-98.

\section{Pre-publication history}

The pre-publication history for this paper can be accessed here: http://www.biomedcentral.com/1741-7015/11/24/prepub

doi:10.1186/1741-7015-11-24

Cite this article as: Lunze et al:: The global burden of neonatal hypothermia: systematic review of a major challenge for newborn survival. BMC Medicine 2013 11:24.

\section{Submit your next manuscript to BioMed Central and take full advantage of:}

- Convenient online submission

- Thorough peer review

- No space constraints or color figure charges

- Immediate publication on acceptance

- Inclusion in PubMed, CAS, Scopus and Google Scholar

- Research which is freely available for redistribution

Submit your manuscript at www.biomedcentral.com/submit
Biomed Central 